\title{
Evaluation of two sample preparation methods for the determination of cadmium, nickel and lead in natural foods by Graphite Furnace Atomic Absorption Spectrophotometry
}

\author{
David Romero-Estévez ${ }^{1}$, Gabriela S. Yánez-Jácome ${ }^{1}$, Karina Simbaña-Farinango ${ }^{1}$, \\ Pamela Y Vélez-Terreros ${ }^{1}$, Hugo Navarrete ${ }^{1, *}$
}

Edited by

Juan Carlos Salcedo-Reyes

(salcedo.juan@javeriana.edu.co)

1. Pontificia Universidad Católica del Ecuador, Centro de Estudios Aplicados en Química CESAQ-PUCE.

*hnavarrete@puce.edu.ec

Received: 06-06-2018

Accepted: 08-07-2019

Published on line: 31-10-2019

Citation: Romero-Estévez D, Yánez-Jácome GS, Simbaña-Farinango $\mathrm{K}$, Vélez-Terreros PY, Navarrete H. Evaluation of two sample preparation methods for the determination of cadmium, nickel and lead in natural foods by Graphite Furnace Atomic Absorption Spectrophotometry, Universitas Scientiarum, 24 (3): 497-521, 2019 doi: 10.11144/Javeriana.SC24-3.eots

Funding:

Pontificia Universidad Católica del Ecuador

Electronic supplementary material: N.A.

OPEN ACCESS

\section{Abstract}

Environmental pollution allows heavy metals to interact with ecosystems, bioaccumulating and passing through the food chain. Animals and humans can consume contaminated species and reach toxic and harmful concentrations in their organisms. While there are international regulatory frameworks for heavy metal contents, these are not always known or suitable for local conditions. This situation calls for the development of locally-applicable analytical methods for the determination of heavy metal concentrations in common vegetal and animal food products. Two established methods (AOAC 999.11, based on sample drying and calcination, and IPN AC-06-00, based on microwave-assisted acid digestion) were comparatively tested at the CESAQ-PUCE laboratory in Quito, Ecuador, to determine their suitability. Sample matrices used were non-industrial, non-organic tomato, lettuce, and beef commonly found in local markets. Heavy metals tested were cadmium, nickel, and lead. Test guidelines and comparative parameters were based on AOAC (2002) and included quantification limits, repeatability variation coefficients, intermediate precision percentages, accuracy and calculated expanded uncertainties. Unlike method AOAC 999.11, method IPN AC-06-00 performance for all parameters was within the range of recommended expected values as per AOAC, and was therefore deemed more suitable to be applied under the local CESAQ-PUCE laboratory conditions. The validation of method IPN AC-06-00 demonstrated its local applicability. In addition, IPN AC-06-00 can be used by similar laboratories to assess contaminants concentrations and improve the baseline information concerning human exposure to toxic metals.

Keywords: AOAC; CESAQ-PUCE; graphite furnace; heavy metal concentrations; microwave-assisted acid digestion; natural food: validation.

\section{Introduction}

Accelerated global industrial development has achieved evident benefits in terms of technology and production, including the food sector. However, in many cases, this development has been accompanied by accelerated deterioration of the environment and has caused the appearance of sub-products and wastes, which undoubtedly entail new detrimental risks to ecosystems in the short, medium and long term. 
Common knowledge among consumers includes awareness of toxic substances that can cause immediate effects or even death. However, this is not the case for another group of substances, like heavy metals, which due to their persistence characteristics can remain unnoticed in organisms and be asymptomatic, migrating from one individual to another through the trophic chain (Nava-Ruíz, Méndez-Armenta 2011).

The natural presence of heavy metals in the environment largely occurs in areas near geological or volcanic deposits (Vigneri, et al.2017). Anthropogenic sources of increased pollution mainly include mining and hydrocarbon exploitation, use of agrochemicals and additives, uncontrolled dumping of industrial waste, and burning of urban waste, among others. Both natural and anthropogenic sources of pollution make it easier for heavy metals to be integrated into the food chain and cause impacts on human health. This in turn becomes a concern of importance for quality control of agricultural and materials production (Astete et al., 2014; de Oliveira et al., 2017; Felix et al., 1986; Martínez et al., 2017; Pérez-Martínez \& Romero 2015; Qureshi et al., 2016).

These metals have a cumulative feature in plant tissues. The exposure begins when animals consume contaminated plants, leading into the potential risk of physiological deterioration and the migration of these pollutants across the food chain. The accumulation in animals' organs and tissues can produce teratogenic and carcinogenic effects. Cadmium oral administration produces effects on kidneys, liver and the hematopoietic, immune, skeletal, and cardiovascular systems (International Programme on Chemical Safety 1992). Nickel oral intake may aggravate vesicular hand eczema and possibly eczema arising on other parts of the body (International Programme on Chemical Safety 1991). Lead intake may produce several cardiovascular effects, hypertension, and protein synthesis damage, among others (International Programme on Chemical Safety 1995). In addition, heavy metals can cross the blood-brain and placental barriers and develop various mutagenic conditions. All these facts promote toxic metals to be prime targets for detection during quality control processes (Bernard 2016; de Oliveira et al., 2017; Foro Intergubernamental de Seguridad Química, 2006; Harangozo, 2016; Lasat, 2000; Lavado-García et al., 2017; Nava-Ruíz \& Méndez-Armenta 2011; Rubio et al. 2004).

The World Health Organization has established global regulations that specify requirements and threshold limit values for different food products components. These regulations are known as the Codex Alimentarius, which aims to ensure safe quality food for people everywhere through international 
standards, guidelines and codes of food practices (FAO/WHO 2016, 2018). Since its inception, Codex Alimentarius committee has identified as one of their needs, to have a general analytical method for the determination of heavy metals in different food products (de Oliveira et al. 2017).

In Ecuador, the Ecuadorian Service for Standardization (INEN) is the governmental agency that issues regulations and specific requirements for a consumer product, including processed food. However, natural plants and animal products are not always included in these regulations, or in other cases, only the microbiological quality of these foods is considered (INEN 2016). There is not enough available information about these contaminants in the Ecuadorian products. Considering that, lettuce and tomato are the most common vegetables that Ecuadorians consume daily in salads (El Comercio 2011a, 2011b); and processed and non-processed beef is the most common meat consumed in Ecuador (El Comercio 2015; El Telégrafo 2015). It is imperative that local laboratories provide reliable methodologies to control the contamination of natural food products.

Research papers and international regulatory frameworks contain a number of methodologies for the determination of heavy metals in several matrices like water, soil, food, and others. (Bakkali et al., 2009; Brizio et al., 2016; Calle et al., 2017; Díaz et al., 2008; García-Rico \& Jara-Marini 1996; Lozano Soldevilla, 2009; Ponce et al., 2006; Rubio et al., 2004; Ruiz Chaves, 2016; Silva Trejos, 2012). However, it is necessary to validate the performance of these techniques under specific conditions of equipment and existing infrastructure in local laboratories.

The main objective of this study was to demonstrate the applicability and to validate an analytical methodology to quantify $\mathrm{Cd}, \mathrm{Ni}$, and $\mathrm{Pb}$ in food by atomic absorption spectrophotometry with graphite furnace.

The purpose of this research is also to establish a new analytical baseline at the investigation laboratory of the Centro de Estudios Aplicados en Química at Pontificia Universidad Católica del Ecuador (CESAQ-PUCE) regarding the human exposure to toxic metals. A part of this purpose is to achieve results that demonstrate traceability, adequate accuracy, and precision for the application of selected methodologies in food products and, with an extension of the initial validation, expand them to other metals.

\section{Procedures}

This study was carried out in three stages: 


\section{Sample preparation}

For testing, five samples of tomatoes (Solanum lycopersicum esculentum Mill), five samples of lettuces (Lactuca sativa var. capitata) and five samples of beef (Bos taurus) were selected as matrices given their frequent consumption and availability in local markets of Quito, Ecuador. The vegetables were chosen from traditional, non-industrial, non-organic farms. These vegetables allowed easy treatment and accuracy close to their expected values during the initial assays.

One kilogram of each sample was bought directly from five selected primary selling places (one of each place). All the samples were refrigerated at $4{ }^{\circ} \mathrm{C} \pm$ $2{ }^{\circ} \mathrm{C}$ until the pre-analysis treatment.

Technical assays of sample preparation were conducted using two reference methods found in the literature and selected for their adaptability to existing conditions at the CESAQ-PUCE laboratory. The methods were applied to fortifications of original samples, after which obtained recoveries were evaluated. These methods are:

a) Sample drying and calcination [international method AOAC 999.11 (AOAC, 1999)], used to analyze lead, cadmium, copper, zinc, and iron. An additional purpose of this study was to verify the method's suitability for quantifying nickel in the selected matrices. Following the methodology's published guidelines, each sample was dried in a Memmert UM 500 stove and subsequently powdered. An amount of $0.50 \mathrm{~g} \pm 0.05 \mathrm{~g}$ (dry wt.) was weighted for each sample, and the required volume of the dilutions of the certified reference materials was added (a process described later in this study). Calcination was then done at $450^{\circ} \mathrm{C}$ in a Thermolyne F62735 furnace, at programmed increments not higher than $50^{\circ} \mathrm{C} / \mathrm{h}$, with the maximum temperature maintained for at least $8 \mathrm{~h}$. The obtained ash was washed adding $1 \mathrm{~cm}^{3}$ to $3 \mathrm{~cm}^{3}$ of medium quality reagent water (APHA, AWWA, \& WEF, 2012) and completely dried, repeating the process until the ash obtained a light gray color. Finally, $5 \mathrm{~cm}^{3}$ of $6 \mathrm{~mol} / \mathrm{dm}^{3}$ hydrochloric acid (Merck, fuming $37 \%$ ) was added to each calcined sample and the resulting solution evaporated to dryness. Each residue obtained was dissolved in $10 \mathrm{~cm}^{3}$ of $0.1 \mathrm{~mol} / \mathrm{dm}^{3}$ nitric acid (Fisher chemical, Certified ACS plus) and raised up to $25 \mathrm{~cm}^{3}$ for its later quantification.

b) Microwave-assisted acid digestion [method IPN AC-06-00 (CIIEMAD-IPN, 2011)], suitable for the digestion of environmental matrices, which present a high content of moisture and organic matter. 
During the preliminary assays, this method presented favorable results for determining metals in vegetables and beef, demonstrated by verifying the specifications and capacities of the Mars 6 CEM microwave, which agreed with those of the microwave used in the literature and allowed extending the assays to the selected beef products (CIIEMAD-IPN 2011). An amount of $0.50 \mathrm{~g} \pm 0.05 \mathrm{~g}$ of each dry sample was weighted and placed inside the digestion Teflon vials. In each vegetable sample vial, $5 \mathrm{~cm}^{3}$ of $65 \%$ nitric acid (Fisher Chemical, Certified ACS plus) and $3 \mathrm{~cm}^{3}$ of $30 \%$ hydrogen peroxide (Fisher Chemical, $30 \%$ Certified ACS) were added as digesters. In the beef samples, $7 \mathrm{~cm}^{3}$ of $65 \%$ nitric acid (Fisher Chemical, Certified ACS plus) were added. The digestion time, temperature gradients and other parameters are shown in Table 1.

The fortifications for the accuracy evaluation of the two methods were prepared adding directly known concentration dilution volumes of reference materials of each metal evaluated:

- Certified Reference Material of Cadmium Certipur ${ }^{\circledR}$, Merck, certificated concentration: $998 \mathrm{mg} / \mathrm{kg} \pm 4 \mathrm{mg} / \mathrm{kg}$ in nitric acid Suprapur ${ }^{\circledR} 0.5 \mathrm{~mol} / \mathrm{dm} 3$, traceable to NIST, density: $1.0133 \mathrm{~g} / \mathrm{cm}^{3}$ at $20^{\circ} \mathrm{C}$.

- Certified Reference Material of Nickel, Inorganic Ventures, certificated concentration: $1003 \mu \mathrm{g} / \mathrm{cm}^{3} \pm 5 \mu \mathrm{g} / \mathrm{cm}^{3}$ in nitric acid in a volume fraction of $2 \%$, traceable to NIST, density: $1.010 \mathrm{~g} / \mathrm{cm}^{3}$ at $20^{\circ} \mathrm{C}$.

- Certified Reference Material of Lead, Inorganic Ventures, certificated concentration: $1001 \mu \mathrm{g} / \mathrm{cm}^{3} \pm 3 \mu \mathrm{g} / \mathrm{cm}^{3}$ in nitric acid in a volume fraction of $0.5 \%$, traceable to NIST, density: $1.002 \mathrm{~g} / \mathrm{cm}^{3}$ at $20^{\circ} \mathrm{C}$.

The dilutions of the corresponding reference materials were prepared as aqueous solutions with medium quality reagent water (APHA, AWWA, WEF, 2012 ) in the proportions necessary to obtain the expected concentration at the final volume before quantification $\left(25 \mathrm{~cm}^{3}\right)$. In the selection phase of the methodology for the validation, ten fortifications of each metal were prepared using different concentrations: $0.25 \mathrm{mg} / \mathrm{kg}$ for cadmium and $1.00 \mathrm{mg} / \mathrm{kg}$ for both nickel and lead. For method AOAC 999.11, the solutions of reference materials were added before the calcination process to the dried and powdered samples, facilitating their homogenization. For the method IPN AC-06-00, dilutions of reference materials were added with the digestion reactants. 
Table 1. Microwave-assisted acid digestion conditions.

\begin{tabular}{lcc}
\hline \multicolumn{1}{c}{ Condition } & Vegetables & Meat \\
\hline Digestion temperature step 1 $\left({ }^{\circ} \mathrm{C}\right)$ & $180 \pm 5$ & $180 \pm 5$ \\
\hline Warm up time step 1 (min) & 10 & 15 \\
\hline Temperature step 1 maintenance time (min) & 15 & 5 \\
\hline Digestion temperature step 2 $\left({ }^{\circ} \mathrm{C}\right)$ & - & $210 \pm 5$ \\
Warm up time step 2 (min) & - & 10 \\
\hline Temperature step 2 maintenance time (min) & - & 10 \\
\hline
\end{tabular}

Original non-fortified samples were treated and analyzed simultaneously with the fortifications to discard possible contamination during the process. Obtained results were compared to the expected values, and recovery rates were calculated with the purpose of confirming the validity and performance of the methods.

After the preparation process in both methods, the samples were filtered using a four grade qualitative filter paper and raised up to $25 \mathrm{~cm}^{3}$.

\section{Determination of metals}

In the second stage, the metal quantification technique for each metal was optimized using a Perkin Elmer HGA 900 graphite furnace coupled to an AAnalyst 400 atomic absorption spectrophotometer equipped with an autosampler and mono-element hollow cathode lamps (Perkin Elmer). The furnace was set with the conditions described in Table 2, in accordance with the technical specifications recommended by the manufacturer in its user manual (Perkin Elmer, 2004). 
Table 2. Graphite furnace conditions for the quantification of cadmium, nickel, and lead.

\begin{tabular}{|c|c|c|c|}
\hline Condition & Cadmium & Nickel & Lead \\
\hline Wavelength (nm) & 228.80 & 232.00 & 283.31 \\
\hline Slit (nm) & $2.7 / 1.35$ & $1.8 / 1.35$ & $2.7 / 1.35$ \\
\hline Trawl gas & \multicolumn{3}{|c|}{ Argon 5.0} \\
\hline Gas flow $(\mathrm{dm} 3 / \mathrm{min})$ & \multicolumn{3}{|c|}{3.0} \\
\hline \multirow{4}{*}{ Temperature ramp (optimized) } & $\begin{array}{c}\text { Reach } 110^{\circ} \mathrm{C} \text { in } 1 \\
\mathrm{~s} \text { and hold } 30 \mathrm{~s}\end{array}$ & $\begin{array}{c}\text { Reach } 110{ }^{\circ} \mathrm{C} \text { in } 1 \\
\text { and hold } 30 \mathrm{~s}\end{array}$ & $\begin{array}{l}\text { Reach } 110^{\circ} \mathrm{C} \text { in } \\
1 \mathrm{~s} \text { and hold } 30 \mathrm{~s}\end{array}$ \\
\hline & $\begin{array}{l}\text { Reach } 130{ }^{\circ} \mathrm{C} \text { in } \\
15 \mathrm{~s} \text { and hold } 30 \mathrm{~s}\end{array}$ & $\begin{array}{c}\text { Reach } 130^{\circ} \mathrm{C} \text { in } 15 \mathrm{~s} \\
\text { and hold } 30 \mathrm{~s}\end{array}$ & $\begin{array}{l}\text { Reach } 130{ }^{\circ} \mathrm{C} \text { in } \\
15 \mathrm{~s} \text { and hold } 30 \mathrm{~s}\end{array}$ \\
\hline & $\begin{array}{l}\text { Reach } 850^{\circ} \mathrm{C} \text { in } \\
10 \mathrm{~s} \text { and hold } 20 \mathrm{~s}\end{array}$ & $\begin{array}{l}\text { Reach } 1400^{\circ} \mathrm{C} \text { in } \\
10 \mathrm{~s} \text { and hold } 20 \mathrm{~s}\end{array}$ & $\begin{array}{l}\text { Reach } 700{ }^{\circ} \mathrm{C} \text { in } \\
10 \mathrm{~s} \text { and hold } 20 \mathrm{~s}\end{array}$ \\
\hline & $\begin{array}{l}\text { Reach } 1800^{\circ} \mathrm{C} \text { in } \\
0 \mathrm{~s} \text { and hold } 5 \mathrm{~s}\end{array}$ & $\begin{array}{c}\text { Reach } 2400^{\circ} \mathrm{C} \text { in } 0 \mathrm{~s} \\
\text { and hold } 5 \mathrm{~s}\end{array}$ & $\begin{array}{c}\text { Reach } 2100{ }^{\circ} \mathrm{C} \text { in } \\
0 \mathrm{~s} \text { and hold } 5 \mathrm{~s}\end{array}$ \\
\hline $\begin{array}{l}\text { Cleaning temperature and time } \\
\text { (optimized) }\end{array}$ & & $\begin{array}{l}\text { Reach } 2450{ }^{\circ} \mathrm{C} \text { in } 1 \mathrm{~s} \\
\text { and hold } 3 \mathrm{~s}\end{array}$ & \\
\hline Injection volume $(\mu \mathrm{l})$ & & 20 & \\
\hline Injection temperature $\left({ }^{\circ} \mathrm{C}\right)$ & & 90 & \\
\hline Chemical Modifiers & $\begin{array}{c}0.015 \mathrm{mg} \mathrm{Pd} \\
+0.01 \mathrm{mg} \\
\mathrm{Mg}\left(\mathrm{NO}_{3}\right)_{2}\end{array}$ & $0.05 \mathrm{mg} \mathrm{Mg}\left(\mathrm{NO}_{3}\right)_{2}$ & $0.2 \mathrm{mg} \mathrm{NH}_{4} \mathrm{H}_{2} \mathrm{PO}_{4}$ \\
\hline Injection volume modifiers $(\mu \mathrm{l})$ & & 5 & \\
\hline
\end{tabular}

\section{Validation method}

\section{Calibration and linearity}

Five different calibration curves were prepared, one for each day of analysis by using an external calibration method, based on the use of a standard solution prepared in different concentration levels, each concentration level within the calibration curves shows the relationship between the amount and peak size for each component.

For the adjustment of each calibration curve, reagent blanks were used, and each level was prepared with direct aqueous dilutions with medium quality 
reagent water (APHA, AWWA, WEF 2012) of the certified reference materials of approximately $1000 \mu \mathrm{g} / \mathrm{dm}^{3}$ of each metal (described in section 2.1). The concentrations of each dilution were $2 \mu \mathrm{g} / \mathrm{dm}^{3}, 4 \mu \mathrm{g} / \mathrm{dm}^{3}, 7 \mu \mathrm{g} / \mathrm{dm}^{3}$ and $15 \mu \mathrm{g} / \mathrm{dm}^{3}$ for cadmium, and $10 \mu \mathrm{g} / \mathrm{dm}^{3}, 20 \mu \mathrm{g} / \mathrm{dm}^{3}, 40 \mu \mathrm{g} / \mathrm{dm}^{3}$ and $60 \mu \mathrm{g} / \mathrm{dm}^{3}$ for nickel and lead.

The linearity was evaluated with regression analysis $\left(\mathrm{r}^{2}\right)$, where a lack-of-fit test was used at $95 \%$ confidence level, for the daily group of all the external standards used (i.e. sample fortifications). Slope (m) and intercept (b) were also calculated.

Statistical calculations were performed using Excel 2016 (Microsoft Office).

\section{Limits of detection and quantification}

The limits of detection and quantification were established experimentally by analyzing quintuplicates of each metal fortifications of samples at lower concentrations. Detection limit was defined as the lower concentration that produces a different and higher signal than the residual noise of the equipment; and the quantification limit was the lower quantifiable concentration with a recovery $(\% \mathrm{R})$ closest to $100 \%$ expected value.

\section{Precision}

The performance of the proposed methods was evaluated in terms of repeatability and intermediate precision. For repeatability (RSDr), quintuplicates of fortification analyses at four levels $(0.1 \mathrm{mg} / \mathrm{kg}, 0.25 \mathrm{mg} / \mathrm{kg}$, $0.5 \mathrm{mg} / \mathrm{kg}$ and $1.0 \mathrm{mg} / \mathrm{kg}$, for cadmium, and $0.5 \mathrm{mg} / \mathrm{kg}, 1.25 \mathrm{mg} / \mathrm{kg}$, $2.5 \mathrm{mg} / \mathrm{kg}$ and $25 \mathrm{mg} / \mathrm{kg}$ for nickel and lead) were carried out. For intermediate precision (RSDp), groups of the quintuplicate trials were carried out during five different days varying the analysts. Results were evaluated by calculating the relative standard deviation (RSD, \%) according to the following equation (AOAC, 2002):

$$
R S D=\frac{s}{X} \times 100
$$

where $\mathrm{s}=$ standard deviation and $\mathrm{X}=$ average concentration.

\section{Accuracy}

The accuracy of the method was demonstrated by the recovery rates calculated in all fortification levels analyzed, according to AOAC guidelines (AOAC, 2002). 


$$
\% \text { recovery }=\frac{(C f-C u)}{C a} \times 100
$$

where $\mathrm{Cf}=$ concentration of the fortified sample, $\mathrm{Cu}=$ concentration of the non-fortified sample and $\mathrm{Ca}=$ calculated (not analyzed) concentration of the analyte added to the samples.

The validation included the demonstration of the smallest variation coefficients for the repeatability, and the fortification recoveries as close as possible to $100 \%$ throughout the entire work range. Subsequently, the expanded uncertainty of each method was calculated, and the highest value was reported to represent all levels of validation.

In addition, five blanks and five non-fortified samples (one for each day of validation) were simultaneously analyzed following the entire method in order to detect signs of contamination during the preparation and quantification process. The blank samples were used to verify the absence of measurements that would interfere with sample results. Results of the quantification of the non-fortified samples were used for the recovery calculations of the fortifications.

After the validation, one-way analysis of variance (ANOVA) was used to determine whether there are any statistically significant differences between the means within each level of fortifications.

Finally, the expanded uncertainty was calculated considering different sources from the sample preparation and quantification. The sources considered were: the expanded uncertainties of the certified reference materials, the calibration of the volumetric material, the calibration of the volumetric equipment (pipettes), the resolution of the measuring equipment and intermediate precision (AOAC, 2002). The linear ranges for each metal were estimated using fortifications in concentrations levels described in section 2.2.3. The linear regression coefficient $\left(\mathrm{r}^{2}\right)$ was evaluated.

\section{Results and discussion}

During the set-up of the sample preparation according to the selected methods, suitability was verified considering the laboratory conditions as 'accurate', being considered those fortification recovery rates between $75.0 \%$ to $120.0 \%$ of expected values according to AOAC guidelines (AOAC, 2002). The results for each method are described in Table 3 and Table 4. In this stage, 
Table 3. Results of the application of method AOAC 999.11 for cadmium, nickel and lead.

\begin{tabular}{|c|c|}
\hline Samples & $\begin{array}{l}\text { Result (mg/kg) / } \\
\text { Recovery (\%) }\end{array}$ \\
\hline \multicolumn{2}{|l|}{ Cadmium } \\
\hline $\begin{array}{l}\text { Concentration in sample of tomato } \\
\text { (quintuplicates average) }\end{array}$ & 0.008 \\
\hline $\begin{array}{l}\text { Fortification: sample Tomato }+0.25 \mathrm{mg} / \mathrm{kg} \\
\text { (average) }\end{array}$ & $0.202 / 77.6 \%$ \\
\hline Concentration in sample of lettuce (average) & 0.000 \\
\hline $\begin{array}{l}\text { Fortification: shows lettuce }+0.25 \mathrm{mg} / \mathrm{kg} \\
\text { (average) }\end{array}$ & $0.214 / 85.6 \%$ \\
\hline Concentration in sample of beef (average) & 0.000 \\
\hline Fortification: beef $+0.25 \mathrm{mg} / \mathrm{kg}$ (average) & $0.137 / 54.8 \%$ \\
\hline \multicolumn{2}{|l|}{ Nickel } \\
\hline Concentration in sample of tomato (average) & 0.011 \\
\hline $\begin{array}{l}\text { Fortification: sample Tomato }+1.00 \mathrm{mg} / \mathrm{kg} \\
\text { (average) }\end{array}$ & $0.817 / 80.6 \%$ \\
\hline Concentration in sample of lettuce (average) & 0.002 \\
\hline $\begin{array}{l}\text { Fortification: shows lettuce }+1.00 \mathrm{mg} / \mathrm{kg} \\
\text { (average) }\end{array}$ & $0.796 / 79.4 \%$ \\
\hline Concentration in sample of beef (average) & 0.000 \\
\hline Fortification: beef $+1.00 \mathrm{mg} / \mathrm{kg}$ (average) & $0.513 / 51.3 \%$ \\
\hline \multicolumn{2}{|l|}{ Lead } \\
\hline Concentration in sample of tomato (average) & 0.018 \\
\hline $\begin{array}{l}\text { Fortification: sample Tomato }+1.00 \mathrm{mg} / \mathrm{kg} \\
\text { (average) }\end{array}$ & $0.721 / 70.2 \%$ \\
\hline Concentration in sample of lettuce (average) & 0.000 \\
\hline $\begin{array}{l}\text { Fortification: shows lettuce }+1.00 \mathrm{mg} / \mathrm{kg} \\
\text { (average) }\end{array}$ & $0.833 / 83.3 \%$ \\
\hline Concentration in sample of beef (average) & 0.000 \\
\hline Fortification: beef $+1.00 \mathrm{mg} / \mathrm{kg}$ (average) & $0.499 / 49.9 \%$ \\
\hline
\end{tabular}


Table 4. Results of the application of method IPN AC-06-00 for cadmium, nickel and lead.

\begin{tabular}{|c|c|}
\hline Samples & $\begin{array}{c}\text { Result (mg/kg) / } \\
\text { Recovery (\%) }\end{array}$ \\
\hline \multicolumn{2}{|l|}{ Cadmium } \\
\hline Concentration in sample of tomato (average) & 0.008 \\
\hline $\begin{array}{l}\text { Fortification: sample Tomato }+0.25 \mathrm{mg} / \mathrm{kg} \\
\text { (average) }\end{array}$ & $0.263 / 102.0 \%$ \\
\hline Concentration in sample of lettuce (average) & 0.001 \\
\hline $\begin{array}{l}\text { Fortification: shows lettuce }+0.25 \mathrm{mg} / \mathrm{kg} \\
\text { (average) }\end{array}$ & $0.244 / 97.2 \%$ \\
\hline Concentration in sample of beef (average) & 0.000 \\
\hline Fortification: beef $+0.25 \mathrm{mg} / \mathrm{kg}$ (average) & $0.256 / 102.4 \%$ \\
\hline \multicolumn{2}{|l|}{ Nickel } \\
\hline Concentration in sample of tomato (average) & 0.011 \\
\hline $\begin{array}{l}\text { Fortification: sample Tomato }+1.00 \mathrm{mg} / \mathrm{kg} \\
\text { (average) }\end{array}$ & $0.992 / 98.1 \%$ \\
\hline Concentration in sample of lettuce (average) & 0.000 \\
\hline $\begin{array}{l}\text { Fortification: shows lettuce }+1.00 \mathrm{mg} / \mathrm{kg} \\
\text { (average) }\end{array}$ & $1.003 / 100.3 \%$ \\
\hline Concentration in sample of beef (average) & 0.000 \\
\hline Fortification: beef $+1.00 \mathrm{mg} / \mathrm{kg}$ (average) & $1.031 / 103.1 \%$ \\
\hline \multicolumn{2}{|l|}{ Lead } \\
\hline Concentration in sample of tomato (average) & 0.018 \\
\hline $\begin{array}{l}\text { Fortification: sample Tomato }+1.00 \mathrm{mg} / \mathrm{kg} \\
\text { (average) }\end{array}$ & $1.071 / 107.1 \%$ \\
\hline Concentration in sample of lettuce (average) & 0.002 \\
\hline $\begin{array}{l}\text { Fortification: shows lettuce }+1.00 \mathrm{mg} / \mathrm{kg} \\
\text { (average) }\end{array}$ & $0.986 / 98.4 \%$ \\
\hline Concentration in sample of beef (average) & 0.000 \\
\hline Fortification: beef $+1.00 \mathrm{mg} / \mathrm{kg}$ (average) & $1.007 / 100.7 \%$ \\
\hline
\end{tabular}


ten fortifications of each metal were analyzed using the concentrations $0.25 \mathrm{mg} / \mathrm{kg}$ for cadmium and $1.00 \mathrm{mg} / \mathrm{kg}$ for both nickel and lead. The average obtained of the ten samples were compared with the acceptance criteria.

Results showed that method IPN AC-06-00 presented recovery rates between $97.2 \%$ and $107.1 \%$, which were within the expected recovery rates of $75.0 \%$ to $120.0 \%$ (AOAC, 2002), compared to the recovery rates obtained when using method AOAC 999.11, which were between $51.3 \%$ and $86.6 \%$. It is believed that the latter was a result of analyte loss due to the various intermediate processes required by method AOAC 999.11, both for drying and calcination.

While it is thought that both methods are valid and well described by the literature in a way that they can be widely applied; due to more fitting results method IPN AC-06-00 was ultimately selected as most suitable to continue with the validation process. As a next step, tomato and beef fortified samples were analized using the selected method to quantify the concentration of each replicate.

\section{Validation results of method IPN AC-06-00}

\section{Linearity}

Instrument calibration was evaluated comparing the linearity of each external standard curve, and it was done once one per day of validation.

The external standard curves obtained for each metal in the vegetable matrix were also used to quantify the beef matrix since the linear range of these two matrices were the same. Curve parameters are shown in Table 5.

The linearity of the curves for all three metals was assessed by regression linear analysis, where the lack-of-fit test was used at $95 \%$ confidence level.

In all calibration curves for all three metals, the regression linear analysis showed results of $\mathrm{r}^{2}$ at or above 0.995, which demonstrates that the calibrations do have a linear tendency and that there exists a direct correlation between the standards concentrations and the absorbance signals.

\section{Limits of detection and quantification}

Detection and quantification limits were calculated applying the method to low-level concentration fortifications for each metal. Results obtained were as follows: 
Table 5. Summary of calibration curve parameters obtained: slope, intercept and regression linear analysis. * Linear adjustment coefficient $\left(\mathrm{r}^{2}\right)$ nearest to 1.00 means the most direct relation between concentration and absorbance of the samples fortifications; it expected to be higher than 0.99 .

\begin{tabular}{|c|c|c|c|c|c|c|}
\hline \multirow{2}{*}{ Metal } & \multirow{2}{*}{ Parameters } & \multicolumn{5}{|c|}{ Calibration Curves } \\
\hline & & 1 & 2 & 3 & 4 & 5 \\
\hline \multirow{3}{*}{ Cadmium } & Slope (m) & 0.0330 & 0.0340 & 0.0315 & 0.0352 & 0.0316 \\
\hline & Intercept (b) & 0.0558 & 0.0446 & 0.0570 & 0.0486 & 0.0583 \\
\hline & $\mathbf{r}^{2^{*}}$ & 0.995 & 1.000 & 0.999 & 0.998 & 1.000 \\
\hline \multirow{3}{*}{ Nickel } & Slope (m) & 0.0041 & 0.0041 & 0.0042 & 0.0042 & 0.0042 \\
\hline & Intercept (b) & -0.0326 & -0.0350 & -0.0351 & -0.0347 & -0.0340 \\
\hline & $\mathbf{r}^{2^{*}}$ & 1.000 & 0.998 & 0.999 & 0.999 & 1.000 \\
\hline \multirow{3}{*}{ Lead } & Slope (m) & 0.0046 & 0.0045 & 0.0046 & 0.0047 & 0.0046 \\
\hline & Intercept (b) & -0.0184 & -0.0190 & -0.0204 & -0.0248 & -0.0190 \\
\hline & $\mathbf{r}^{2^{*}}$ & 1.000 & 0.998 & 0.999 & 1.000 & 0.998 \\
\hline
\end{tabular}

Detection Limits: the concentration that produced a different signal than the equipment noise.

In vegetable matrix: $60 \mu \mathrm{g} / \mathrm{kg}$ for cadmium and $150 \mu \mathrm{g} / \mathrm{kg}$ for both nickel and lead.

In beef matrix: $50 \mu \mathrm{g} / \mathrm{kg}$ for cadmium and $100 \mu \mathrm{g} / \mathrm{kg}$ for both nickel and lead.

Quantification Limits : the concentration with a recovery rate between $75.0 \%$ and $120.0 \%$ (AOAC, 2002).

In vegetable matrix: $100 \mu \mathrm{g} / \mathrm{kg}$ for cadmium, $500 \mu \mathrm{g} / \mathrm{kg}$ for nickel and 400 $\mu \mathrm{g} / \mathrm{kg}$ for lead.

In beef matrix: $100 \mu \mathrm{g} / \mathrm{kg}$ for cadmium and $500 \mu \mathrm{g} / \mathrm{kg}$ for both nickel and lead. 


\section{Accuracy and precision}

The results of the precision assessment were evaluated for repeatability and intermediate precision. Repeatability was evaluated at four concentration levels, and the relative standard deviations (RSD) were calculated for each level to compare with the limits established (AOAC, 2002). Limits for trace levels should not exceed $8.00 \%$ for repeatability. The results are shown in Table 6.

Results showed that RSD values were within the recommended range and that the method indicated good repeatability for all concentrations. The highest RSD obtained was $3.70 \%$ for vegetable and $4.85 \%$ beef matrices.

The determination of intermediate precision was calculated from quintuplicate repetitions for five dissimilar analysts in different days. The RSD was used as a measure of the precision of replicas of samples for five different conditions (analysts and days) (Table 6). The highest RSD obtained was $4.14 \%$ for vegetable and $4.70 \%$ beef matrices. Compared to the limits proposed (AOAC, 2002): maximum RSD of $16 \%$. Intermediate precision was satisfactory in both matrixes.

Accuracy of the method was assessed by calculating the recovery rates obtained in every repetition (see Table 6). The recovery rates ranges were between 93.0 and 107.3 for vegetables and between 93.2 and 108.0 for beef samples. Results obtained for recoveries were satisfactory, being within the range proposed (AOAC, 2002) of $75.0 \%$ to $120.0 \%$ for related trace concentrations.

One-way ANOVA analysis was acceptable for all the validation levels. All the $F$ values calculated were below the $F$ value tabulated $(2.8661, \alpha=0.05)$ for the number of repetition of samples used (quintuplicates, 5 days of validation). It demonstrated that the dependent variable was normally distributed in each validation level. It also means that the samples population variances in each group were equal.

Method IPNAC-06-00 displayed an acceptable performance for vegetables and beef analyzed, with calculated expanded uncertainties $(\mathrm{k}=2)$ being equal or lower than $14.3 \%$ and $15.1 \%$, respectively.

Linear ranges for each metal were, $0.1 \mathrm{mg} / \mathrm{kg}$ to $1.0 \mathrm{mg} / \mathrm{kg}$ for cadmium, $0.5 \mathrm{mg} / \mathrm{kg}$ to $2.5 \mathrm{mg} / \mathrm{kg}$ for nickel and lead,and 0.5 to $2.5 \mathrm{mg} / \mathrm{kg}$ for both vegetable and beef matrices. 
Table 6. Summary of mean values ( $\mathrm{mg} / \mathrm{kg}$ ), repeatability (RSDr, \%), intermediate precision (RSDp, \%) and accuracy (\%) results for the five samples in each level $(\mathrm{mg} / \mathrm{kg})$ of determination of cadmium, nickel and lead in vegetables and beef under method IPN AC-06-00 and the recommended values for AOAC (2002).

\begin{tabular}{|c|c|c|c|c|c|c|}
\hline \multirow{2}{*}{ Levels } & \multicolumn{3}{|c|}{ Vegetables } & \multicolumn{3}{|c|}{ Beef } \\
\hline & $\begin{array}{c}\text { Mean } \\
\text { values }\end{array}$ & RSDr / RSDp & Accuracy & $\begin{array}{c}\text { Mean } \\
\text { values }\end{array}$ & $\begin{array}{c}\text { RSDr / } \\
\text { RSDp }\end{array}$ & Accuracy \\
\hline \multicolumn{7}{|c|}{ Cadmium } \\
\hline 0.10 & 0.11 & $3.59 / 4.07$ & 106.9 & 0.10 & $3.13 / 3.30$ & 95.7 \\
\hline 0.25 & 0.26 & $2.37 / 2.43$ & 101.1 & 0.24 & $2.76 / 2.53$ & 95.3 \\
\hline 0.50 & 0.47 & $0.99 / 1.13$ & 93.0 & 0.54 & $1.23 / 1.44$ & 108.0 \\
\hline 1.00 & 1.04 & $3.70 / 4.14$ & 103.5 & 1.02 & $2.36 / 2.34$ & 101.9 \\
\hline \multicolumn{7}{|c|}{ Nickel } \\
\hline 0.50 & 0.53 & $1.17 / 1.26$ & 103.0 & 0.50 & $2.93 / 3.21$ & 100.2 \\
\hline 1.25 & 1.35 & $1.19 / 1.38$ & 107.3 & 1.24 & $4.85 / 4.70$ & 99.1 \\
\hline 2.50 & 2.51 & $0.93 / 1.03$ & 99.8 & 2.35 & $3.48 / 3.95$ & 93.9 \\
\hline 25.00 & 25.31 & $0.71 / 0.82$ & 101.2 & 23.44 & $3.50 / 3.71$ & 93.8 \\
\hline \multicolumn{7}{|c|}{ Lead } \\
\hline 0.50 & 0.54 & $1.88 / 2.01$ & 105.2 & 0.49 & $2.51 / 2.65$ & 99.0 \\
\hline 1.25 & 1.33 & $1.53 / 1.67$ & 104.6 & 1.30 & $1.49 / 1.74$ & 104.2 \\
\hline 2.50 & 2.52 & $0.91 / 0.98$ & 100.1 & 2.33 & $1.79 / 2.07$ & 93.2 \\
\hline 25.00 & 25.05 & $0.89 / 0.90$ & 100.1 & 23.85 & $2.09 / 2.24$ & 95.4 \\
\hline $\begin{array}{l}\text { Recommended } \\
\text { maximum } \\
\text { values }\end{array}$ & -- & $8.00 / 16.00$ & $\begin{array}{c}75.0 \text { to } \\
120.0\end{array}$ & -- & $8.00 /$ & $\begin{array}{c}75.0 \text { to } \\
120.0\end{array}$ \\
\hline
\end{tabular}

Additionally, it should be mentioned that the microwave-assisted acid digestion method is considerably shorter in assay time and allows a substantial reduction in any analyte losses that may exist when it is carried out in a single process and in a completely closed system. 


\section{Conclusions}

Considering the recovery rates of the fortifications used, method IPN AC-06-00, using microwave-assisted acid digestion, displayed a better performance than method AOAC 999.11 within the detection parameters of heavy metals established for CESAQ-PUCE and under current regulations for this type of analysis. Despite not having been originally designed for the analysis of nickel, method IPN AC-06-00 also demonstrated being valid for that purpose. Infrastructure and operational capacity of CESAQ-PUCE were found to be appropriate. Although the assays were limited to two vegetable samples and one animal sample; the results provided a concrete path to continue developing method IPN AC-06-00 as a first-line tool for the determination of food safety in relation to cadmium, nickel, and lead. This enables to expand the assays to other vegetable and animal products for human consumption and other heavy metals of toxicology relevance, such as arsenic and mercury.

Food sample preparation for analysis by microwave-assisted acid digestion was better suited than traditional acid digestion and calcination methods, since it required shorter digestion times and allowed for simultaneous and continuous processing of multiple samples with temperature and pressure monitoring. Microwave-assisted acid digestion also required lower amounts of reagents (nitric acid and hydrogen peroxide) and, being carried out in a closed vessel, prevented unintended contact with fumes or acid vapors as occurs in the other open techniques. Finally, microwave-assisted acid digestion reduced the level of analyte losses by volatilization and contamination of the samples.

The Graphite Furnace Atomic Absorption Spectrophotometry quantification permits quantification limits in the order to micrograms per kilogram against the Flame Atomic Absorption techniques, which permits higher quantification limits in the order to milligrams per kilogram. In comparison with other techniques available for the determination of heavy metals (ICP-OES, ICP-MS), the operating expenses of the graphite furnace technique are lower.

Finally, it is necessary for local laboratories to optimize and validate each analytical methodology before its use, in order to confirm that each specific procedure used is adequate for its proposed use. In addition, the validation processes allow local laboratories to apply standard methodologies with their available technology and develop the analysis related to food safety. 


\section{Acknowledgements}

Authors gratefully acknowledge the Pontificia Universidad Católica del Ecuador for its financial support to the implementation of this study. The study was carried out entirely using the infrastructure and equipment of the CESAQ-PUCE laboratory.

\section{Conflict of interest}

The authors of this paper belong to the CESAQ-PUCE laboratory, which, independently of any possible interest, develops research projects within the PUCE, which is a non-profit higher education institution.

\section{References}

AOAC. AOAC Official Method 999.11 Determination of Lead, Cadmium, Copper, Iron, and Zinc in Foods. 1999. http://img.21 food.cn/img/biaozhun/20100108/177/11285282.pdf

AOAC. Guidelines for single laboratory validation of chemical methods for dietary supplements and botanicals. $A O A C$ International, 1-38, 2002.

https://www.aoac.org/aoac_prod_imis/AOAC_Docs/ StandardsDevelopment/SLV_Guidelines_Dietary_Supplements.pdf

APHA, AWWA, WEF. Standard Methods for the Examination of Water and Wastewater. (L. S. C. Eugene W. Rice, Rodger B. Baird, Andrew D. Eaton, Ed.) 22nd ed, 2012. Maryland: APHA, AWWA, WEF.

Astete J, Gastañaga MC, Pérez D. Niveles de metales pesados en el ambiente y su exposición en la pobblación luego de cinco años de exploración minera en las Bambas, Perú 2010, Revista Peruana de Medicina Experimentaly Salud Pública, 31(4): 695-701, 2014.

doi: $10.17843 /$ rpmesp.2014.314.120

Bakkali K, Ramos N, Souhail B, Ballesteros E. Characterization of trace metals in vegetables by graphite furnace atomic absorption spectrometry after closed vessel microwave digestion, Food Chemistry, 116(2), 590-594, 2009.

doi: 10.1016/j.foodchem.2009.03.010

Bernard A. Confusion about cadmium risks: The unrecognized limitations of an extrapolated paradigm, Environmental Health Perspectives, 124(1): 1-5, 2016.

doi: $10.1289 /$ ehp.1509691 
Brizio P, Benedetto A, Squadrone S, Curcio A, Pellegrino M, Ferrero M, Abete MC. Heavy metals and essential elements in Italian cereals, Food Additives \& Contaminants: Part B, 9(4): 261-267, 2016.

doi: 10.1080/19393210.2016.1209572

Calle MB, Devesa V, Fiamegos Y, Vélez D. Determination of Inorganic Arsenic in a Wide Range of Food Matrices using Hydride Generation - Atomic Absorption Spectrometry, Journal of Visualized Experiments, 112(September): 1-8, 2017.

doi: $10.3791 / 55953$

CIIEMAD-IPN. Método general por microondas de digestión ácida en matrices ambientales, 0, 1-15, 2011.

http://www.ciiemad.ipn.mx/SGC/Documents/Procedimientos/IPN_ AC-06-00.pdf

de Oliveira TM, Peres JA, Felsner ML, Justi KC. Direct determination of $\mathrm{Pb}$ in raw milk by graphite furnace atomic absorption spectrometry (GF AAS) with electrothermal atomization sampling from slurries, Food Chemistry, 229: 721-725, 2017.

doi: $10.1016 /$ j.foodchem.2017.02.143

Díaz O, Encina F, Recanarren E, Del Valle S, Pastene R, Montes S, Figueroa A. Estudio de la concentración de arsénico, mercurio, plomo y fenantreno en la macha (Mesodesma donacium. Implicancias alimentarias y toxicológicas, Revista Chilena de Nuricion, 35(1): 53-60, 2008.

doi: $10.4067 /$ S0717-75182008000100007

El Comercio. En la Sierra hay seis tipos de lechugas, Actualidad Negocios, p. 3, 2011 a.

https://www.elcomercio.com/actualidad/negocios/sierra-hay-seistipos-de.html

El Comercio. Ocho variedades de tomate riñón están en los mercados locales, Actualidad - Negocios, pp. 24-26, 2011 b.

https://www.elcomercio.com/actualidad/negocios/ocho-variedadesde-tomate-rinon.html

El Comercio. En ocho provincias se concentra el mayor consumo de cárnicos, Revista Lideres, p. 3, 2015.

https://www.revistalideres.ec/lideres/consumo-carnicos-ecuador.html 
El Telégrafo. Los ecuatorianos consumen 142 gramos de carnes al día, Sociedad, pp. 4-5, 2015.

https://www.eltelegrafo.com.ec/noticias/sociedad/6/los-ecuatorianosconsumen-142-gramos-de-carnes-al-dia

FAO/WHO. Acerca del Codex. FAO. 2016.

http://www.fao.org/fao-who-codexalimentarius/about-codex/es/

FAO/WHO. Norma General para los Contaminantes y las Toxinas Presentes en los Alimentos y Piensos Codex 193-1995, 2018.

http: / / www.fao.org/fao-who-codexalimentarius/sh-proxy/ es $/$ ? $\operatorname{lnk}=1 \&$ url $=$ https $\% 253 \mathrm{~A} \% 252 \mathrm{~F} \% 252 \mathrm{Fworkspace}$ fao.org\% $\% 252 \mathrm{Fs}$ ites $\% 252 \mathrm{Fcodex} \% 252 \mathrm{FStandards} \% 252 \mathrm{FCODEX} \% 2 \mathrm{BSTAN} \% 2 \mathrm{~B} 193$ 1995\%252FCXS_193s.pdf

Felix I, Mite F, Carrillo M, Pino M. Avances De Investigacion Del Proyecto Determinación de Metales Contaminantes en Cultivos de Exportación y su Repercusion sobre la Calidad de los Mismos, VIII Congreso Ecuatoriano de La Ciencia Del Suelo, 1-8, 1986.

http://www.secsuelo.org/wp-content/uploads/2015/06/5-Determinacionde-metales-contaminantes-Felix-I.pdf

Foro Interguvernamental de Seguridad Química. Metales pesados: ¿necesidad de más acciones globales? Informe de evento paralelo de Suiza 23 de septiembre de 2006, Foro Interguvernamental de Seguridad Quimica (IFCS), 41(22): 1-16, 2006.

https://www.who.int/ifcs/documents/forums/forum5/8inf_rev1_sp.pdf

García-Rico L, Jara-Marini, M. Aplicación de Microondas en la Digestión de Hígado de Bovino para la Cuantificación de Metales Pesados, Contaminación Ambiental, 12(1): 41-44, 1996.

https://www.revistascca.unam.mx/rica/index.php/rica/article/ view/31003/28711

Harangozo L. Risk elements in selected types of vegetables, Potravinarstvo, 10(1): 625-630, 2016.

https://doi.org/10.5219/654

INEN. Catálogo de Normas Técnicas. Quito: INEN, (2016). http://apps.normalizacion.gob.ec/descarga/

International Programme on Chemical Safety. Nickel, nickel carbonyl, and some nickel compounds Health and Safety Guide (HSG 62), 1991.

http://www.inchem.org/documents/hsg/hsg/hsg062.htm 
International Programme on Chemical Safety. Environmental Health Criteria: Cadmium (EHC 134), The International Programme on Chemical Safety (IPCS). 1992.

http://www.inchem.org/documents/ehc/ehc/ehc134.htm

International Programme on Chemical Safety. Environmental Health Criteria: Inorganic lead (EHC 165). 1995.

http://www.inchem.org/documents/ehc/ehc/ehc165.htm

Lasat MM. The Use of Plants for the Removal of Toxic Metals from Contaminated Soil, American Association for the Advancement of Science National Service Center for Environmental Publications (NSCEP), 2000.

https://nepis.epa.gov/Exe/ZyNET.exe/9100FZE1.TXT?ZyActionD=ZyDocument $\&$ Client $=$ EPA $\&$ Index $=2000+$ Thru $+2005 \&$ Docs $=\&$ Query $=\&$ Time $=\&$ EndTime $=\&$ Se archMethod $=1 \&$ Toc Restrict $=n \&$ Toc $=\&$ To cEntry $=\&$ QField $=\&$ QFieldYear $=\&$ QFieldMonth $=\&$ QFieldDay $=\&$ In $\mathrm{tQFieldOp}=0 \&$ ExtQFieldOp $=0 \& \mathrm{XmlQuery}=\&$ File $=\mathrm{D} \% 3 \mathrm{~A} \% 5 \mathrm{Czyfi}$ les\%5CIndexData\%5C00thru05\%5CTxt\%5C00000024\%5C9100FZE1. txt \&User $=$ ANONYMOUS \&Password=anonymous \&SortMetho$\mathrm{d}=\mathrm{h} \% 7 \mathrm{C}-\&$ MaximumDocuments $=1 \&$ FuzzyDegree $=0 \&$ Image Quality $=$ r $75 \mathrm{~g} 8 / \mathrm{r} 75 \mathrm{~g} 8 / \mathrm{x} 150 \mathrm{y} 150 \mathrm{~g} 16 / \mathrm{i} 425 \&$ Display $=\mathrm{hpfr} \& D$ efSeekPa$\mathrm{ge}=\mathrm{x} \&$ SearchBack $=$ ZyActionL\&Back $=$ ZyActionS\&BackDesc $=$ Results page $\&$ MaximumPages $=1 \&$ ZyEntry $=1 \&$ SeekPage $=x \&$ $\& y$ PURL

Lavado-García J, Puerto-Parejo L, Roncero-Martín R, Moran J, Pedrera-Zamorano J, Aliaga IJ,Canal-Macias M. Dietary Intake of Cadmium, Lead and Mercury and Its Association with Bone Health in Healthy Premenopausal Women, International Journal of Environmental Research and Public Health, 14(12): 1437, 2017.

doi: $10.3390 /$ ijerph14121437

Lozano Soldevilla G. Metales pesados: aportaciones al estudio toxicológico de especies y alimentos marinos en las Islas Canarias. Universidad de la Rioja. 2009.

https:/ / dialnet.unirioja.es / servlet/tesis?codigo $=38669$

Martínez Z, González MS, Paternina J, Cantero M. Contaminación de suelos agrícolas por metales pesados, zona minera El Alacrán, Córdoba-Colombia, Temas Agrarios, 22(2): 20-32, 2017.

doi: $10.21897 /$ rta.v22i2.941

Nava-Ruíz C, Méndez-Armenta M. Efectos neurotóxicos de metales pesados (cadmio, plomo, arsénico y talio), Archives of Neuroscience, 16(3): 140-147, 2011.

https://www.medigraphic.com/pdfs/arcneu/ane-2011/ane113f.pdf 
Pérez-Martínez I, Romero FM. Uso de parámetros indirectos para la evaluación de la contaminación de suelos por metales pesados en una zona minera de San Luis Potosí, México. Boletín de La Sociedad Geológica Mexicana, 67(1): 1-12, 2015.

http:// boletinsgm.igeolcu.unam.mx/bsgm/vols / epoca04/6701/\%281\%29Perez.pdf

Perkin Elmer. User manual AAnalyst 400 AA Spectrometer. Waltham: Perkin Elmer. 2004.

Ponce R, Farias S, Bovi Mitre G, Vélez D, Montoro R. Determinación de arsénico total e inorgánico en carne y vísceras de camélidos (Lamina glama) autóctonos de la provincia de Jujuy, Argentina, Revista Facultad de Agronomía de la UBA, 26(1): 105-109, 2006.

http://www.produccion-animal.com.ar/produccion_de_camelidos/ Llamas/110-arsenico_carne_llamas.pdf

Qureshi AS, Hussain MI, Ismail S, Khan QM. Evaluating heavy metal accumulation and potential health risks in vegetables irrigated with treated wastewater, Chemosphere, 163: 54-61, 2016.

doi: 10.1016/j.chemosphere.2016.07.073

Rubio C, Gutiérrez AJ, Martín-Izquierdo RE, Revert C, Lozano G, Hardisson A. El plomo como contaminante alimentario, Revista de Toxicología, 21(2-3): 72-80, 2004.

http://www.redalyc.org/articulo.oa?id=91921303

Ruiz Chaves I. Metodologías analíticas utilizadas actualmente para la determinación de mercurio en músculo de pescado, Medio Ambiente y Salud, 16(26): 113-122, 2016.

doi: 10.15517/PA.V16I26.25187

Silva Trejos P. Digestión en horno de microondas para determinación de contenido de hierro y zinc totales en alimentos, Tecnología En Marcha, 25: 96-100, 2012.

doi: $10.18845 /$ tm.v25i3.461

Vigneri R, Malandrino P, Gianì F, Russo M, Vigneri P. Heavy metals in the volcanic environment and thyroid cancer, Molecular and Cellular Endocrinology, 457(5): 73-80, 2017.

doi: $10.1016 /$ j.mce.2016.10.027 


\section{Evaluación de dos métodos de preparación de muestras para la determinación de cadmio, níquel y plomo en alimentos naturales por espectrofotometría de absorción atómica con horno de grafito}

Resumen: La contaminación ambiental hace que los metales pesados interactúen con los ecosistemas, se bioacumulen y pasen a través de la cadena alimenticia. Animales y humanos pueden consumir especies contaminadas y alcanzar concentraciones tóxicas y perjudiciales en sus organismos. Aunque existen marcos regulatorios internacionales para los contenidos de metales pesados, no siempre son conocidos o no son adecuados para las condiciones locales. Esta situación exige el desarrollo de métodos analíticos aplicables localmente para la determinación de concentraciones de metales pesados en productos alimenticios comunes de origen vegetal y animal. Se compararon dos métodos establecidos (AOAC 999.11, basado en secado y calcinación de la muestra, e IPN AC-06-00, basado en digestión ácida asistida por microondas), en el laboratorio CESAQ-PUCE de Quito, Ecuador, para determinar su idoneidad. Las matrices de muestras utilizadas fueron tomate, lechuga y carne no industriales y no orgánicas, que se encuentran en mercados locales. Los metales pesados evaluados fueron cadmio, níquel y plomo. Las guías para desarrollar las pruebas, así como los parámetros comparativos, se basaron en la AOAC (2002) e incluyeron límites de cuantificación, coeficientes de variación de reproducibilidad, porcentajes de precision intermedia, precisión y cálculo de incertidumbres expandidas. A diferencia del método AOAC 999.11, el comportamiento del método IPN AC-06-00 para todos los parámetros estuvo dentro del rango de valores esperado recomendado por la AOAC, y por tanto fue considerado más adecuado para ser aplicado bajo las condiciones de laboratorio locales del CESAQ-PUCE. La validación del método IPN AC-06-00 demostró su aplicabilidad local. Además, el IPN AC-0600 puede ser usado por laboratorios similares para determinar las concentraciones de contaminantes y mejorar la información de línea base relativa a la exposición humana a metales tóxicos.

Palabras clave: AOAC; CESAQ-PUCE; horno de grafito; concentraciones de metales pesados; digestión ácida asistida por microondas; alimentos naturales; validación. 


\section{Avaliação de dois métodos de preparação de amostras para determinaçáo de cádmio, níquel e chumbo em alimentos naturais por espectrofotometria de absorção atômica em forno de grafite}

Resumo: A poluição ambiental ocasiona que metais pesados interatuem com ecossistemas, bioacumulando e passando através da cadeia alimentar. Animais e humanos podem consumir espécies contaminadas e atingir concentrações tóxicas e prejudiciais em seus organismos. Embora existam normas regulatórias internacionais para o conteúdo de metais pesados, elas nem sempre são conhecidas ou adequadas às condições locais. Essa situação exige o desenvolvimento de métodos analíticos aplicáveis localmente para a determinação das concentrações de metais pesados em produtos alimentícios comuns de origem vegetal e animal. Dois métodos estabelecidos (AOAC 999.11, com base na secagem e calcinação da amostra, e IPN AC-06-00, com base na digestão ácida assistida por micro-ondas) foram testados comparativamente no laboratório CESAQ-PUCE em Quito, Equador, para determinar sua adequação. As matrizes de amostra utilizadas foram tomate, alface e carne não-industrializadas, não-orgânicas, comumente encontrados em mercados locais. Os metais pesados testados foram cádmio, níquel e chumbo. As guias do teste e os parâmetros comparativos foram baseados em (AOAC (2002)) e incluíram limites de quantificação, repetitividade (coeficientes de variação), precisão intermediaria (porcentagens), exatidão e incertezas expandidas calculadas. Diferentemente do método AOAC 999.11, o desempenho do método IPN AC-06-00 para todos os parâmetros estava dentro da faixa dos valores recomendados conforme AOAC e, portanto, foi considerado mais adequado para ser aplicado nas condições locais do laboratório CESAQ-PUCE. A validação do método IPN AC-06-00 demonstrou sua aplicabilidade local. Além disso, o IPN AC-06-00 pode ser usado por laboratórios semelhantes para determinar as concentrações de contaminantes e melhorar as informações básicas sobre a exposição humana a metais tóxicos.

Palavras-chave: AOAC; CESAQ-PUCE; forno de grafite; concentração de metais pesados; digestão ácida assistida por micro-ondas; alimentos naturais; validação. 


\section{David Romero-Estévez}

David Romero-Estévez, born in Quito, Ecuador (1987), Chemical Sciences degree with a mention in Analytical Chemistry (2010) and a Master's degree in Safety and Prevention of Occupational Hazards in Universidad Técnica Equinoccial, Quito, Ecuador (2015). Principal Researcher and Technical manager at the Centro de Estudios Aplicados en Química from Pontificia Universidad Católica del Ecuador. His main line of research is toxic metals in food.

ORCID: 0000-0003-1381-9464

\section{Gabriela S. Yánez-Jácome}

Gabriela S. Yánez-Jácome, born in Latacunga, Ecuador (1987). Master's degree in Advanced Fine Chemistry obtained in the University of Cordoba, Cordoba, Spain (2013). Principal Researcher and Quality assurance manager at the Centro de Estudios Aplicados en Química from Pontificia Universidad Católica del Ecuador (CESAQ-PUCE), Ecuador. Her research is aligned to the determination of environmental and food contaminants, mainly of mercury and its compounds. Evaluation of mercury exposure and risk assessment in human health.

ORCID: 0000-0002-0361-2729

\section{Karina Simbaña-Farinango}

Karina Simbaña-Farinango, born in Quito-Ecuador (1986). Chemical Sciences degree with a mention in Analytical Chemistry. Currently, she is studying a Master's degree in Environmental Management at the International SEK University, Quito, Ecuador. She is a researcher at the Centro de Estudios en Química from Pontificia Universidad Católica del Ecuador (CESAQ-PUCE) Ecuador. Her main line of research is environmental pollution and sustainable management of natural resources.

ORCID: 0000-0002-2779-1856 


\section{Pamela Y Vélez-Terreros}

Pamela Y Vélez-Terreros, born in Quito - Ecuador (1989). She obtained her Chemical Science Degree specialized in Analytical Chemistry on PUCE, Ecuador (2014) and her Master degree in Food Development and Innovation on Barcelona University, Spain (2019). She collaborated as an analyst in the Environmental and Chemical Services Laboratory. Actually, she is part of the investigation team at the Centro de Estudios Aplicados en Química (CESAQ - PUCE) in Ecuador.

ORCID: 0000-0002-2366-7313

\section{Hugo Navarrete}

Hugo Navarrete, born in Quito, Ecuador (1969), Educational Science and Second Teaching degree in the Specialization of Biology (2003) and Doctor in Biological Sciences (2014). Research Director, Principal Professor at the Pontificia Universidad Católica del Ecuador, General manager at the Centro de Estudios Aplicados en Química (CESAQPUCE). His research is aligned with ethnobotanical biodiversity, ecology, biotechnology, use and conservation of natural resources.

ORCID: 0000-0002-5262-9754 